\title{
DiJiTALLEŞMENIN EKONOMIK, TEKNOLOJiK, TOPLUMSAL VE ETIK ETKILERININ ULUSLARARASI RAPORLAR ÜZERINDEN ANALIZi ${ }^{1}$
}

\author{
Analysis Of The Economic, Technological, Social and Ethical Effects Of Digitalization \\ Via International Reports \\ Dr. Mert KÜÇÜKVARDAR 2 \\ Bağımsız Araştırmacı \\ 0000-0001-5205-4674 \\ Arş. Gör. Alaattin ASLAN ${ }^{3}$ \\ Marmara Üniversitesi, Illetişim Fakültesi \\ 0000-0001-5053-9256
}

Öz

Dijital teknolojiler birçok sorunun çözümünde kilit bir rol üstlenmektedir. Özellikle Kovid-19 salgınıyla birlikte değişen çalışma koşulları, eğitim, sosyalleşme, etkileşim gibi olguların odak noktası dijital teknolojiler ve dijital becerilerden geçmektedir. Bu nedenle özellikle uluslararası raporlarda ele alınan dijital dünya etkisinin irdelenmesi konuyla ilgili keskin sınırların belirlenmesine yardımcı olacaktır. Bu bağlamda çalışmada literatür taramasından yararlanılmıştır. Dijitalleşmenin ortaya çıkardığı etki, yenilik ve problemler Dünya Ekonomik Forumu (WEF), Ekonomik İşbirliği ve Kalkınma Örgütü (OECD), Birleşmiş Milletler Eğitim, Bilim ve Kültür Örgütü (UNESCO), Avrupa Birliği (AB) ve Avrupa Konseyi (AK)'nin yayınladığı raporlar çerçevesinde incelenmiş ve içerik analizi yapılmıştır. Uluslararası raporlarda dijitalleşmenin etkileri, hangi alanları kapsadığı, üzerinde durulan ortak noktalar, dijital ekosistemin teşvik edilip edilmediği, dijital etik açısından sorunların olup olmadığı gibi sorulara cevap aranmıştır. Raporlarda dijitalleşmenin ortaya çıkardığı etkiler oldukça kapsamlı olmasına karşın temel olarak ekonomik, teknolojik ve toplumsal etki ile etik yaklaşımlar çerçevesinde toplanmıştır. Belirlenen 4 kategori çerçevesinde uluslararası raporlar incelendiğinde ekonomik etkinin iş gücü piyasasının dijital dönüşümü, ekonomik çerçevede uluslararası dijital işbirliği, dijital bir ekosistem teşviki, sürdürebilir bir büyüme gibi çeşitli konu başlıklarıyla ele alındığı görülmektedir. Teknolojik etkiler bakımından ise şeffaflık ve hesap verilebilirlik, siber güvenlik problemleri, teknolojik sorumluluk, insani denetim mekanizması, dijital araçlardaki tutarsızlık raporlarda üzerinde durulan konuları oluşturmaktadır. Toplumsal etki bakımından ise dijital hayat için etkin politikalar oluşturma, kolluk kuvvetlerinin dijital veri kullanımı ve son dönemlerdeki raporlarda Kovid-19 salgınıyla birlikte önem kazanan dijital eğitim, e-bilgi, konularının tartışıldı̆̆ gözlemlenmiştir. Son olarak etik yaklaşım açısından uluslararası raporlar incelendiğinde dijital dünya ile birlikte ortaya çıkan gizlilik ve veri paylaşımının toplumsal etkisi, enformasyon ve iletişim etiği, insan merkezli değerler ve adalet gibi konuların üzerinde durulduğu görülmektedir.

Anahtar Kelimeler: Dijital Dünya, Dijital Yașam, Dijital Etki, Dijital Illetișim

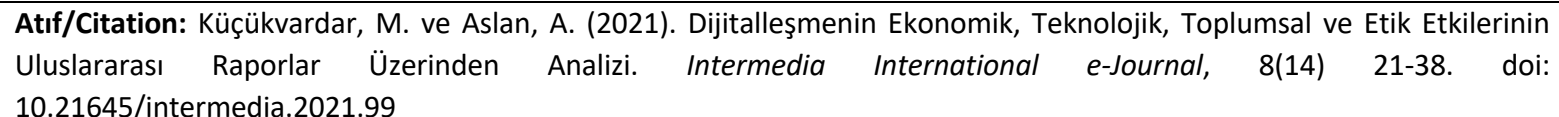

\footnotetext{
1 Makalenin Türü: Araştırma Makalesi / Research Article

2 e-mail: mertkvardar@gmail.com

3 e-mail: alaattin.aslan@marmara.edu.tr
} 
Extended Abstract: Digital technologies play a key role in solving many problems. With the Covid-19 outbreak, working conditions, education, socialization, and interaction phenomena have changed. For this reason, it is necessary to examine the impact of the digital world mentioned in international reports. At this stage, literature review was used in the study. The digitalization reports published by the World Economic Forum (WEF), the Organization for Economic Co-operation and Development (OECD), the United Nations Educational, Scientific and Cultural Organization (UNESCO), the European Union (EU), and the Council of Europe (EC) have been examined. Although the effects of digitalization in the reports are quite extensive, they are mainly gathered within the framework of economic, technological, and social impact. When the international reports are examined, it is seen that the economic impact is discussed with various topics such as the digital transformation of the labor market, international digital cooperation in the economic framework, the incentive of a digital ecosystem, and a sustainable growth. In terms of technological impacts, transparency and accountability, cybersecurity problems, technological responsibility, humanitarian control mechanism, are the subjects emphasized in the reports. In terms of social impact, it was observed that effective policies for digital life, digital education, e-information, were discussed. Finally, in terms of ethical approach, the social impact of privacy and data sharing, information and communication ethics, and digital justice are discussed.

Digital transformation triggers massive data production and use. This situation draws the attention of institutions and especially international organizations. New approaches are needed to keep up with transformation. The emerging ideas focus on solving the digitalization effect. Especially in recent years, international reports have been published on the process of digitalization and its effects. In the reports, the change, development, and problems caused by digitalization are mainly discussed. These problems are discussed in the reports in the context of economy, technology, social impact, and ethical approach. Content analysis was carried out by considering the international reports mentioned. Content analysis is a categorization process performed within the framework of the basic assumptions of research. The most critical point in content analysis is that the assumptions about the categories are prepared in advance as a result of the researcher's knowledge. When the reports are examined, it is seen that the effects of digitalization are gathered in economic, technological, social, and ethical fields. For this reason, the items on digital life effects discussed in the reports were evaluated under four categories. It is aimed to determine the economic, technological, social effects, and ethical approaches of digitalization. The study also sought answers to some of the following questions:

1- What areas are the effects of digitalization in international reports?

2- Are there common points regarding the effects of digitalization in international reports?

3- Is a common digital ecosystem encouraged in international reports?

4- Are there any problems in the existence, implementation, and control of norms related to digital ethics in international reports?

New technologies need to be designed to benefit the norms. Their use is seen as the main basis of the ethical approach. In this context, it has been tried to determine what social problems might be in the content of the reports before they actually appear. Considering the innovations brought about by technological changes, it is seen that the current order has not yet fully adapted to the digital transformation. The flow of information generated by digital technologies, a large number of online actions reveal many digital "footprints". Digital technologies are the basis for digital transformation in all sectors of economies and societies. Digital technologies, which play a key role in solving many problems, have raised certain questions with the Covid-19: How can Digital Transformations be measured across all sectors, especially the economy? What will replace existing business models with the Covid-19 outbreak? What will be the future economic and socio-cultural activities in the light of digitalization after the pandemic? How will education continue to be given to many people who should be at home? Will digital rights be truly protected with digitization processes? Many such questions are waiting to be resolved. Basically, the potential of digital technologies should be used. Systems, where citizens are protected and basic services, are provided easily from digital environment should be adopted. Economic, socio-cultural interactions should be supported in a way that is beneficial for the society. While giving priority to the use of technology, a policy that protects human rights should be adopted. All of these will be an important start at the point of solving the problems. Governments should carefully monitor international reports for the development of a reliable digital ecosystem. This will help ease the transition process.

Key Words: Digital World, Digital Life, Digital Impact, Digital Communication 


\section{GíRiş}

Dijitalleşme günümüz toplumsallığının yaşadığı en derin değişim ve dönüşümü temsil etmektedir. Bu durum öylesine bir hal almıştır ki neredeyse dijitalleşmeyen her şey yok olmak ile karşı karşıya kalmaktadır. En basit anlamıyla dijitalleşme fiziksel dünyada var olan herhangi bir şeyin $0^{\prime} l a r$ ve $1^{\prime}$ ler yardımıyla bilgisayarların anlayabileceği, yorumlayabileceği, depolayabileceği, iletebileceği bir formata dönüştürmesi durumunu temsil etmektedir. Dijitalleşme bir tarafıyla analog dünyanın bilgisayarlara aktarılması iken diğer taraftan ise dünyada fiziksel olarak hiç var olmamış yazılımların, yapay zekânın, siber uzamların vb. temsilini de içermektedir. Gündelik yaşantımızın neredeyse her anını bir simülasyon evrenine taşımakla, aynı zamanda ihtiyaç ve isteklerimizi yine bir simülasyon ortamından sağlamakla meşgulüz. Dijitalleşmenin ilk safhalarında bankacılık işlemlerinin banka şubesine gitmeden gerçekleştirebilmenin konforu şimdilerde aklımıza gelebilecek her türlü ihtiyaç için gerçekleşmeye doğru yol almaktadır. Barınmak için bir evi veya karnınızı doyurmak için yemeği ve seyahat edip rahatlama isteğini bile bir simülasyon evreni sayesinde sağlamak son derece makul görünmektedir. Bunların yanı sıra yeni teknolojilerin hayatımıza kattığı ve katacağı kolaylıklar yanında birçok sorunu beraberinde getirmektedir. Dijitalleşmenin en temel dayanağı veridir; yani bilgisayarların anlayacağı bir dile dönüştürülmüş 0 ve $1^{\prime}$ ler ile ifade edilebilen her türlü enformasyon paketçiğidir. Bu verilerin insanlar tarafından hayatlarının teknoloji sayesinde kolaylaştırılması için gönüllü bir şekilde dijital ortamlara aktarılıyor olması ve aynı zamanda akıllı cihazlar tarafından sürekli üretilmesi bu denli değerli olan bu madenin ciddi bir biçimde tehlikede olmasına neden olmaktadır. İnsanlar gündelik işlerini, arzularını duygularını, kızgınlıklarını vb. hemen hemen her şeyi ifade etmek için dijital iletişim platformlarını kullanmakta bu şekilde konum, alışveriş, ihtiyaç vb. verilerin yanı sıra duygu ve düşüncelerini bile bir enformasyon paketçiğine dönüştürmektedirler (Serrano-Puche, 2015, s. 6). Üretilen bu sonsuz verilerin işlenmesi, gruplanması, kategoriye sokulması ile ilgilenen büyük veri şirketleri bu verilerin ticari bir niteliğe dönüştürülmesi yolu ile çok ciddi kazançlar elde etmektedirler (Keskin, 2020, s. 129). Değerli herhangi bir metanın bu kadar kolay ulaşılabilir olması dijitalleşmenin en büyük eksikliği olarak göze çarpmaktadır.

Hayatımızı bu denli değiştiren ve her anına etki eden bu kavramın anlaşılması günümüz sosyal bilimcilerinin ana uğraş alanlarından birini oluşturacak kadar önemli görünmektedir. Toplumsallığın sağlanmasının temel kaynakları olan ekonomi, toplumsal birliktelik, teknolojik ilerleme gibi kavramlar üzerinden tartışılan (Küçükvardar, Aslan, \& Bayrakcı, 2020),(Önür \& Kalaman, 2016) ve ortaya çıkan her yeni kavramın yaşadığı temel anlamda hangi eksene bağı̆ı bir tartışmanın konusu olacağı sorunsalı yine dijitalleşme içinde geçerli olmaktadır. Özellikle içinde bulunduğumuz durumun temsili ve gelecekteki teknolojilerin (İoT, Drone) ve insan durumlarının (Trashümanizm, Bedensel Tekillik) toplumsallığı nasıl etkileyeceği üzerine bir kestirimde bulunmak oldukça önemlidir. Bu bağlamda çalışmanın amacı, dijitalleşmenin ortaya çıkardığı etkilerin uluslararası raporlar üzerinden yapılan bir okuma ile hangi alanlar üzerine yoğunlaştı̆̆ı, dijitalleşmenin etkilediği alanların toplumsal yaşam üzerinde ne gibi izler bıraktığı, bunun yerleşik düzen üzerindeki etkilerinin belirlenmesi, etik tartışmalar ve ortaya atılan normlar açısından uygulama/denetim gibi eksikliklerin değerlendirilmesi ve ortak sorunların çalışma yöntemiyle belirlenen kategoriler üzerinden ele alınmasıdır.

\section{1. Çalışmanın Amaç ve Yöntemi}

Çalışmada uluslararası bir vakıf olarak Dünya Ekonomik Forumu (WEF), uluslararası ekonomik kalkınma ve işbirliği örgütü (OECD), Birleşmiş Milletler Eğitim, Bilim ve Kültür Örgütü (UNESCO), uluslararası düzenin işleyişindeki rolü itibariyle küresel düzeyde bir örgüt olarak Birleşmiş Milletler (BM), bölgesel düzeyde siyasi ve ekonomik bir örgütlenme olan Avrupa Birliği (AB), Avrupa çapında insan hakları ve hukuku savunmak amacıyla kurulan Avrupa Konseyi (AK)'nin yayınladığı dijitalleşme raporlar ele alınmıştır.

Bahsi geçen uluslararası raporlar çerçevesinde içerik analizi yapılmıştır. Ole Holsti (1969, s. 14) içerik analizi yöntemini, "içeriklerin belirli özellikleri çerçevesinde nesnel aynı zamanda sistematik olarak tanımlanması ve çıkarımlar yapmaya yönelik herhangi bir teknik" olarak tanımlamaktadır. Weber (1990, s. 117) ise içerik analizi yöntemini metinlerden geçerli çıkarımlar yapmak için bir dizi yol kullanan bir araştırma metodolojisi olarak 
tanımlanmıştır. Rosengren (1981, s. 11), içerik analizini "izlenimci, sezgisel, yorumlayıcı analizlerden sistematik, katı metinsel analizlere kadar uzanan bir analitik yaklaşımlar" olarak tanımlamıştır.

İçerik analizi, araştırmanın temel varsayımları çerçevesinde yapılan bir kategorileştirme işlemidir. Bu işlemde en kritik nokta, bahsi geçen kategorilere yönelik varsayımların, araştırmacının kurumsal, ampirik birikimleri neticesinde önceden hazırlanmış olmasıdır. Kategorilerin oluşturulması araştırma sorularının sistematik bir şekilde analiz edilip değerlendirilmesine yardımcı olabilecek en önemli aşamalardan biridir. Bu nedenle kategorilerin açık ve net biçimiyle formüle edilmesi ve araştırma sorularına uygun bir biçimde ele alınıp, tanımlanması gerekmektedir. İçerik analizinde yer alan kategorilerin araştırma sorularını da içermesi, önemli bilgilerin kullanılmasına yardımcı olmaktadır (Gökçe, 2006, s. 57-58). Kategorilerin ele alınıp, belirlenmesi aşamasında bazı özelliklerin değerlendirilmesi gerekmektedir. Kategoriler oluşturulurken homojen olmalıdır. Özellikle birbirine benzer nitelikteki öğeler aynı kategoriler içerisinde yer almalıdır. Aynı zamanda kategoriler soruna uygun ve anlamlı biçimiyle verilmeli, mesajın bütününü ele alacak şekilde kapsamlı olmalıdır (Bilgin, 2006).

Raporlar incelendiğinde dijitalleşmenin oluşturduğu etkilerin ekonomik, teknolojik, toplumsal ve etik alanlarında toplandığı görülmüştür. Bu nedenle raporlarda ele alınan dijital yaşam etkilerine yönelik maddeler ilgili tabloda bahsi geçen 4 kategori içerisine yerleştirilmiştir. Raporlarda belirlenen maddeler aynı zamanda dijitalleşmeyle birlikte görülen yönetim boşluklarının değerlendirildiği WEF, "Global Technology Governance" 2021 raporunda yer alan 7 madde açısından da değerlendirilmiştir. Uluslararası kuruluşların dijitalleşme raporlarına yönelik değerlendirmelerden hareketle dijitalleşmenin ekonomik, teknolojik, toplumsal etkileri ve bunlara yönelik ortaya konulan etik yaklaşımların belirlenmesinin amaçlandığı bu çalışmada ayrıca aşağıdaki bazı sorulara cevap aranmıştır:

1. Uluslararası raporlarda dijitalleşmenin etkileri temel olarak hangi alanları kapsamaktadır?

2. Uluslararası raporlarda dijitalleşmenin etkilerine yönelik ortak noktalar bulunmakta mıdır?

3. Uluslararası raporlarda ortak bir dijital ekosistem teşvik edilmekte midir?

4. Uluslararası raporlarda dijital etik ile ilgili normların varlığı, uygulanması ve denetimi açısından sorunlar bulunmakta mıdır?

Bahsi geçen sorulara yönelik ele alınan uluslararası raporlardaki dijitalleşmeyle ilgili ekonomik, teknolojik, toplumsal etkiler, etik yaklaşım ve raporlar üzerinde durulan ortak noktalar tablo üzerinde detaylandırılmıştır.

\section{Dijitalleşmenin Uluslararası Raporlar Üzerinden Okunması}

Dijitalleşme bugünümüzü şekillendirmekte ve geleceğimizi belirleyecek muazzam bir ekonomik ve sosyal potansiyel sunmaktadır. Bu durum toplumun her kesimine büyük sorumluluklar getirmektedir. Şüphesiz değişim ve dönüşümlerde insanların süreç içerisinde yaşadıkları en büyük korku yeniliğe ayak uyduramama ve onlara karşı güven duymanın zaman almasıdır. Bu bağlamda güven, dijital dünyada merkezi bir kaynak haline gelmektedir. Dijitalleşmeyi bir hedef olarak önüne alan devletler, şirketler, sivil toplum kuruluşlar vb. için toplumda güven kazanmak en önemli amaçlardan bir halini almaktadır. Bu durum yeni dönem için sorumlu ve etik çalışmanın dijital dönüşümler için kritik başarı faktörleri olduğunu ortaya çıkarmaktadır (Pwc, 2020, s. 4). Bununla birlikte dijital dönüşümün yaptığı etkiyi ölçmek giderek zorlaşmaktadır. Dijital dönüşümün büyük bir veri üretimi ve kullanımını tetiklemesi kurumların ve özellikle de uluslararası kuruluşların dikkatini çekmektedir. Dönüşüme ayak uydurmak amacıyla yeni yaklaşımlara duyulan ihtiyaç sonucunda ortaya çıkan fikirler dijital araçların etkisinin çözümüne odaklanmaktadır. Özellikle son yıllarda dijitalleşme süreci ve bunun etkilerine yönelik uluslararası raporlar yayınlanmaktadır. Raporlarda temel olarak dijitalleşmenin ortaya çıkardığı değişim, gelişim ve sorunlar; ekonomi, teknoloji, toplumsal etki ve etik yaklaşım bağlamında tartışılmaktadır. 
Dijital dünyaya yönelik kapsamlı çözümlemelerde bulunulması gerektiğini vurgulayan örgütlerden biri olan WEF 1971 yılında kâr amacı gütmeyen bir amaçla ortaya çıkan Uluslararası Kamu-Özel İşbirliği Örgütüdür. WEF, küresel, bölgesel ve endüstri alanlarını organize etmek ve geleceğine yön vermek amacıyla toplumun önde gelen siyasi, ticari, kültürel ve diğer liderlerini bir araya getirmektedir (WEF, 2021). Özellikle son yıllarda dijitalleşme süreçlerine yönelik çok sayıda rapor yayınlamıştır. WEF'in 2021 yılı içerisinde yayınlandığı "Global Technology Governance" raporu teknolojik sorunları daha önceki raporlardan hareketle özetler niteliktedir. Raporda dijitalleşmeyle birlikte görülen yönetim boşluklarına değinilmiştir (WEF, 2021, s. 9-11):

1. Sınırlı veya düzenleme eksikliği: Yapay zekâ ve diğer teknolojilerin uzun vadeli sonuçları bilinmemektedir. Örneğin, yüz tanıma teknolojisine yönelik kapsamlı bir düzenleme bulunmamaktadır.

2. Kötüye kullanım veya amaçsız kullanım yoluyla teknolojinin olumsuz etkisi: Halkı etkilemek veya kişilere, kuruluşlara ve hükümetlere zarar vermek amacıyla yeni araçlar bulunmaktadır. Örneğin, kaynağı belirsiz saldırılarda kripto para birimleri kullanılmaktadır.

3. Teknolojik sorumluluk: Özerk sistemler veya blok zinciri tabanlı teknolojilerin hesap verebilirliği noktasında boşluk bulunmaktadır. Örneğin, merkezi olmayan özerk kuruluşlar yasal statü açııından belirsizliğini korumaktadır.

4. Gizlilik ve veri paylaşımı: Bilgi paylaşımı için paylaşılan teknik standartlar veya üzerinde anlaşmaya varılmış yönetişim çerçeveleri bulunmamaktadır. Örneğin, veriler kurumsal amaçlarla zaman zaman kötüye kullanılmaktadır.

5. Kolluk kuvvetleri tarafından erişim ve kullanım: Kolluk kuvvetlerinin teknolojiler tarafından üretilen verileri nasıl kullanacağına dair belirli kurallar bulunmamaktadır. Örneğin, polis veri tabanı için toplanan veriler bazen istismar edilmektedir.

6. Siber ve diğer güvenlik endişeleri: Güvenli YZ ürünleri oluşturma noktasında çeşitli riskler bulunmaktadır. Örneğin, insansız hava araçlarının saldırı amaçlı kullanıldığı durumlarda sisteme düşman tarafından sızma ihtimali bulunmaktadır.

7. Insan denetimi: YZ destekli sistemlerde ne kadar insan katılımının olması gerektiği konusunda belirsizlik yaşanmaktadır. Güvenli ve etkili bir dijital süreç için ne kadar insan etkisi bulunması gerektiği hususunda uzlaşı bulunmamaktadır. Örneğin, otonom sistemler tarafından alınan kararlara dayalı olarak ortaya çıkan araba veya uçak kazalarında sorumluluk durumu tartışılmaktadır.

OECD' raporlarında hızlanan küreselleşme ve teknolojik gelişmelerin yol açtığı sosyal, ekonomik ve çevresel düzeyde çeşitli zorluklardan bahsedilmektedir. Bunların temelini dijitalleşme süreci ve YZ teknolojileri oluşturmaktadır. OECD raporlarında bu konuları detaylı bir şekilde ele almaktadır. Mayıs 2019'da OECD üyesi ülkeler tarafından Yapay Zekâ Konsey Tavsiyesi kararları alınmıştı (OECD, 2019, s. 1-3). OECD ilkeleri, yenilikçi ve güvenilir, insan haklarına ve demokratik değerlere saygı duyan dijitalleşme süreçlerini teşvik etmektedir. Bu ilkeler aynı zamanda hükümetler tarafından YZ bağlamında kabul edilen ilk ilkelerdir. OECD üyelerinin dışında, Arjantin, Brezilya, Kosta Rika, Malta, Peru, Romanya ve Ukrayna gibi diğer ülkeler de dijital dünya ile ilgili verilen tavsiyelere bağıı kalmışlardır. Dijitalleşme ile birlikte görülen gelişmelerin ışı̆ıında alınan OECD tavsiye kararları çoğunlukla YZ üzerinden değerlendirilmektedir (OECD, 2019). OECD tavsiyeleri yasal olarak bağlayıcı olmamasına karşın ülkeler tarafından ciddiye alınmaktadır. OECD ayrıca hükümetlere dijital süreçlerin yönetimi konusunda belirli tavsiyelerde bulunmaktadır. Veri ve bilgilerin kolayca paylaşılmasının hükümetlerce desteklenmesi, dijital altyapıya yönelik katkıda bulunulması bu tavsiyelerin başında gelmektedir. Toplumda adil bir kullanımın desteklenmesi, sektörler arasındaki iş birliğinin sağlanması, kamu ve özel yatırımların kolaylaştırıması gibi konu başlıkları da uluslararası raporlarda ele alınan ekonomik, teknolojik ve toplumsal etkilerin temelini oluşturmaktadır. 
UNESCO dijitalleşme ile birlikte ortaya çıkan gelişmeleri raporlarında ele alıp değerlendiren bir başka BM kuruluşudur. Dijitalleşme açısından raporlarında teknolojinin belirli eğilimleri yönlendirdiğine vurgu yapmaktadır. Özellikle eğitim açısından bakıldığında bir yandan uzaktan eğitim teknolojileri etkinliklerini artırırken diğer tarafından mikro öğrenme, planlama gibi öğrenci ihtiyaçlarının teknoloji tarafından karşılanması UNESCO'nun vurguladığı temel konuları oluşturmaktadır. Esnek öğrenme fırsatlarıyla birlikte eğitim kurumlarının kapasiteleri önemli ölçüde değişmektedir. Özellikle bilim açısından bakıldığında süreçlerin her geçen gün dijitalleştirilmesi, çeşitli sektörlerde çalışan insanların konulara vakıf kalabilmek için belirli aşamalarda eğitime dönmeleri gerekliliğini ortaya çıkarmaktadır (UNESCO, 2020, s. 70).

Dijital dünya etkisini raporlarında geniş biçimde ele alan bir başka oluşum ise Avrupa Komisyonu'dur. AK 2020 yılı içerisinde yayınladığı birçok raporda dijitalleşme ile ortaya çıkan ekonomik, kültürel ve teknolojik değişimlere yönelik çözümlemeler sunmuştur. Avrupa'nın dijital geleceğini şekillendirmek amacıyla toplanan AK, Kovid-19 salgınıyla birlikte Avrupa'daki dijital geçişin hızlandırılması gerektiğini vurgulamaktadır. Ekonomik anlamda ise dijital tabanlı tek bir pazar oluşturmak, Avrupalı şirketlerin büyümesi ve daha geniş ölçeklenmesini sağlamak hedeflenmektedir. Ayrıca bunlar dijital dünyanın daha da ön plana çıktığı pandemi döneminde $A B$ için temel amaçlar olarak değerlendirilmektedir (European Commission, 2019).

$A B$ ise dijitalleşme fırsatlarını değerlendirmek, ekonomik temeli güçlendirmek, teknolojik egemenliği sağlamak, küresel rekabet gücünü güçlendirmek, yeşil bir dünyayı desteklemek, istihdam yaratmak ve vatandaşların yaşamlarını iyileştirmek gibi amaçları benimsemiştir. Bunlar AB üye ülkelerinin hemfikir kaldığı konuları oluşturmaktadır. Dijital dönüşüm, uluslararası düzeyde politikacılar, ekonomistler ve endüstri liderleri arasında ortaya çıkardığı ekonomik, teknolojik ve toplumsal etki bakımından şiddetli bir tartışma konusudur. Uluslararası raporlarda ele alınan ekonomik, teknolojik, toplumsal ve etik konular ile ortak kesişim noktaları Tablo 1'de özetlenmiştir:

Tablo 1: Uluslararası raporlarda tartışılan ortak konular ve etkiler

\begin{tabular}{|l|l|c|c|c|c|c|}
\hline \multirow{5}{*}{ EKONOMiK ETKi } & WEF & OECD & UNESCO & AB $^{4}$ & AK \\
\hline & İşücü piyasasının dijital dönüşümü & & $\checkmark$ & & $\checkmark$ & $\checkmark$ \\
\hline & $\begin{array}{l}\text { Güvenilir YZ için uluslararası } \\
\text { işbirlikleri }\end{array}$ & $\checkmark$ & $\checkmark$ & & & $\checkmark$ \\
\hline & Dijital bir ekosistem teşviki & & $\checkmark$ & & $\checkmark$ & $\checkmark$ \\
\hline & $\begin{array}{l}\text { Kapsayıcı büyüme, sürdürülebilir } \\
\text { gelişme ve refah süreci }\end{array}$ & & $\checkmark$ & & $\checkmark$ & $\checkmark$ \\
\hline \multirow{5}{*}{ TEKNOLOJiK ETKi } & Şeffaflık ve açıklanabilirlik & & $\checkmark$ & & $\checkmark$ & \\
\hline & Siber ve diğer güvenlik problemleri & $\checkmark$ & $\checkmark$ & & & $\checkmark$ \\
\hline & $\begin{array}{l}\text { Teknolojik sorumluluk, hesap } \\
\text { verebilirlik }\end{array}$ & $\checkmark$ & $\checkmark$ & & $\checkmark$ & $\checkmark$ \\
\hline & Insani denetim & $\checkmark$ & & & & $\checkmark$ \\
\hline & Dijital araçlarda tutarsızlık & $\checkmark$ & & & & $\checkmark$ \\
\hline \multirow{5}{*}{ TOPLUMSAL ETKi } & $\begin{array}{l}\text { Dijital hayat için etkin bir politika } \\
\text { ortamı şekillendirme }\end{array}$ & & $\checkmark$ & & $\checkmark$ & $\checkmark$ \\
\hline & $\begin{array}{l}\text { Kolluk Kuvvetlerinin dijital veri } \\
\text { kullanımı }\end{array}$ & $\checkmark$ & & & $\checkmark$ & \\
\hline
\end{tabular}

\footnotetext{
${ }^{4} A B$ 'nin yürütme organı olan Avrupa Komisyonunun yayınladığı raporlar bir bütün olarak $A B$ başlığı altında değerlendirilmiştir.
} 


\begin{tabular}{|l|l|c|c|c|c|c|}
\hline & Sınırlama ve düzenleme eksikliği & $\checkmark$ & & & & \\
\hline & Dijital eğitim ve E-bilgi & & & $\checkmark$ & $\checkmark$ & $\checkmark$ \\
\hline \multirow{3}{*}{ ETiK YAKLAŞıM } & Gizlilik ve veri paylaşımı & $\checkmark$ & & & $\checkmark$ & \\
\hline & Enformasyon ve iletişim etiği & & & $\checkmark$ & & \\
\hline & insan merkezli değerler ve adalet & & $\checkmark$ & & $\checkmark$ & $\checkmark$ \\
\hline
\end{tabular}

WEF, OECD, UNESCO, AB ve AK dijitalleşme ile birlikte ortaya çıkan etki düzeyi ve çeşitli konuları raporlarında değerlendirmektedir. Bahsi geçen bu uluslararası raporlardan hareketle ekonomik düzeydeki dijital dönüşümün, dijitalleşme konusunda uluslararası işbirliklerinin, dijital bir ekosistem oluşumunun ve sürdürülebilir bir refah sürecinin oluşturulması süreçlerini kapsadığı görülmektedir. Teknolojik etki düzeyine bakıılığında ise raporlarda ağırıklı olarak dijital sistemlerin şeffaflı̆ı, siber düzeyde ortaya çıkan güvenlik problemleri, teknoloji tabanlı ortaya çıkan sorunlarda sorumluluk ve hesap verebilirlik düzeyi konuları üzerinde tartısmaların sürdürdüğü görülmektedir. Raporlara toplumsal etki düzeyinde bakıldığında ise dijital dünya için etkin bir politika belirlenmesi, dijitalleşme sonucu ortaya çıkan sınırlama eksikliği, özellikle Kovid-19 süreciyle birlikte önem kazanan dijital eğitim süreci gibi konular göze çarpmaktadır. Etik yaklaşımlar açısından dijital verilerin gizliliği ve paylaşımı, insan merkezli değerler ve son olarak dijital dünyadaki hızlı veri akışındaki haber-iletişim etiği konuları ele alınmaktadır.

\subsection{Dijital Hayat ve Ekonomik Süreçler}

Dijital ekonomi, geleneksel iş modellerini kısmen veya tamamen dijital modellere dönüştürmek için birçok yenilikçi yaklaşımın oluşturulmasını içermektedir. Ekonomide dijitalleşme, süreçlerin mikro dönüşümünden ulus devletlerin gündemlerinin dönüşümüne kadar sıklıkla dönüşüm olgusuyla açıklanmaktadır. Aynı zamanda modernleşme ile giderek daha fazla ilişkilendirilmektedir. Ekonomik sektörleri etkileyen, neredeyse evrensel bağlanabilirlik ve her yerde bulunan bilgi işlem ile karakterize edilen, büyük miktarda verinin üretilmesi ve kullanılmasından kaynaklanan geniş kapsamlı bir dijital dönüşüm yaşanmaktadır. Dijitalleşme artık ekonominin tüm sektörlerini kapsayan dinamik bir süreci temsil etmektedir. Değer zinciri alanındaki geleneksel çözümler dijital dönüşüm sürecine tabi bir hale gelmektedir (Reinartz, Wiegand, \& Imschloss, 2019). Küresel pazar gelişiminin dinamikleri, dijital ekonominin gelişimine dayanmaktadır. Geleneksel değer zincirleri dijitalleşmeye tabi hale gelmiştir. Klasik çözümlere (değer zincirinin geleneksel yapısı) dayalı iş modelleri de kısmen veya tamamen dijitalleşmeye tabidir ve böylece verimliliklerini ve etkinliklerini artırmak için yeni fırsatlar elde etmektedirler. İnternet ekonomisi, esasen önemli dinamikleri ve değişim hızı ile karakterize edilmektedir. Hayatın çeşitli alanlarının hızla dijitalleşmesi, bugünün Bilgi Toplumuna doğru bir kaymaya neden olmuştur (Wirtz, 2019).

Dördüncü Sanayi Devrimi, fiziksel, dijital ve biyolojik alanlar arasındaki ayrımı bulanıklaştıran bir dizi teknoloji aracılığıyla ortaya çıkmaktadır. Endüstri 4.0, ürünlerin nasıl tasarlandığının, üretildiğinin, kullanıldığının ve işletildiğinin yanı sıra servis işlemlerini de dönüştürmektedir. Bir yapı olarak Endüstri 4.0, endüstriyel ve ekonomik faaliyetlerin her yönünü kapsayan bir dönüşümdür. Bu tüm sektörlerin yeni sistemlere ve / veya yaşam biçimlerine toplam bir dönüşümüdür. Dönüşüm fiziksel, dijital ve biyolojik dünyaların yakınsaması, nanoteknoloji, yapay zekâ, robotik, biyonik, genetik ve 3D baskı dâhil olmak üzere 'yıkıcı teknolojiler' olarak görülen teknolojik gelişmelerle ilgilidir. Endüstri 4.0 kapsamında, dijital teknolojiler endüstriyel ürün ve hizmetlerle bağlantılı olduğundan ve hibrit ürünlere dönüştürüldüğünden, endüstri ve hizmetler arasındaki ayrım daha az alakalı hale gelmektedir. Aslında, hem "Nesnelerin İnterneti" hem de "Hizmetlerin İnterneti" terimleri, Endüstri 4.0'ın unsurları olarak kabul edilmektedir (European Parliament, 2016).

Bukth ve Heeks (2017, s. 13), dijital ekonomiyi nelerin oluşturduğuna dair bir kavramsallaştırma sunmaktadır. Ekonominin dijital teknolojilere en doğrudan bağlı kısmı "dijital sektör" olarak anılmaktadır. Bunlar temel dijital mal ve hizmetler üreten bilişim teknolojileri sektörüdür. "Dijital ekonomi", "dijital sektör" ise dijital 
hizmetler ve platform hizmetlerinden oluşmaktadır. Bu ekonomik çıktının, dijital ürün veya hizmetlere dayalı bir iş modeliyle öncelikli olarak dijital teknolojilerden elde edilen kısmı olarak tanımlanmaktadır. Dijitalleşme, dijital ekonominin potansiyeline dayalı olarak işletmelerin ekonomik başarısını etkilemektedir (Bleicher \& Stanley, 2018).

Bilişim teknolojilerinin çeşitli alanlarda yaygınlık kazanmasından bu yana işgücü ve süreçleri ciddi bir dönüşüm geçirmiştir. Burada özellikle iletişim teknolojilerinin payı büyüktür. Castells (2010), dünyayı etkileyen iletişim teknolojilerinden olan kablosuz iletişimin temel özelliğinin hareketlilik değil, sürekli bağlantı olduğunu belirtmiştir. Dijital süreçlerle birlikte bu teknolojiler insanların işyerinde ve genel olarak ekonomik süreçlerde yaşadıkları pek çok zorluk için geniş fırsatlar yaratmaktadır. Ekonomik bağlamda bakıldığında bilgi üretmek, işlemek, paylaşmak ve işlem yapmak için dijital teknolojilerin büyük ölçüde benimsenmesiyle tetiklenen ekonomik ve sosyal dönüşüm son 1 sene içerisinde etkisini hissettirmiştir. Ekonomik açıdan çalışma biçimlerinin değişimi çalışanların yeni "normallere" uyum sağlaması, çoğunlukla çevrim içi olan toplantılar, dijital ortama taşınan ofis işleri, yeni iş kalıpları birçok toplumda görülmektedir.

Dijitalleşme ile birlikte ekonomik alanda ön plana çıkan bir diğer konu ise adil ve rekabetçi dijital ekonominin oluşturulmasıdır. Adil ve rekabetçi bir dijital ekonomi AB'nin dijital stratejisini ifade etmektedir. Bu strateji yenilikçi ve hızı büyüyen yeni girişimlerden, küçük işletmelerden oluşan canlı bir topluluğun finansmana erişmesine ve genişlemesine olanak tanıyan bir modeldir. Aynı zamanda dijital hizmetler yasası bağlamında çevrim içi hizmetler için kuralların netleştirmesi ve çevrim içi platformların sorumluluğunu güçlendirmeyi amaçlamaktadır (European Commission, 2019).

Dijital teknolojilerin gelişmesiyle birlikte veri ekonomisi de önem kazanmıştır. AB üye ülkeleri, dijital çağda ön plana çıkmak ve gelişmek için veri ekonomisinin önemini kabul etmektedir. Yayınlanan raporlarda ekonomik açıdan bakıldığında insan merkezli çeşitli yenilikçi hizmetlerin temel alındığı, sektörler arasında iş birliğinin sağlandığı bir veri paylaşımı ağı oluşturulması hedeflenmektedir. Bu bağlamda AB önümüzdeki beş yıl boyunca dijital dönüşümü kolaylaştıracak stratejiler önermektedir. AB'nin iletişimden sorumlu temsilcileri Avrupa veri stratejisine yönelik bir yasaya ilişkin girişimde bulunmuştur. Yasa temel olarak ekonomiyi dijital alana daha çok entegre edebilecek sektörlerin desteklenmesi, kurumlar arasında verilerin kullanılabilirliğinin teşvikini amaçlamaktadır (European Commission, 2020).

Uluslararası Çalışma Örgütü (ILO) daha çevresel bir ekonomiye geçişin mümkün olduğunu ifade etmektedir. Çalışma örgütü ayrıca, enerji sektöründeki sürdürülebilir uygulamaların benimsenmesi, elektrikli araçların kullanılması ve gelecekteki binalarda enerji verimliliğinin artırılması yoluyla 2030 yılına kadar küresel olarak 24 milyon yeni iş potansiyelinin oluşturulabileceğini tahmin etmektedir (United Nations, 2019). Buna karşın, McKinsey gibi araştırma şirketlerinin raporları, 2030 yılına kadar 800 milyon kişinin işlerini otomasyona kaptırabileceğini öne sürmektedir. Aynı zamanda araştırma şirketlerinin anketleri şuandaki çalışanların çoğunun gelecekte iyi ücretli bir iş bulmak için gerekli eğitime veya becerilere sahip olmadıklarından endişe duyduğunu ortaya koymaktadır (McKinsey Global Institute, 2017).

Küresel düzeydeki salgın ile birlikte önemini artıran dijitalleşme iş süreçlerinin zorunlu kapatmalar yaşadığı ve sosyal mesafe önlemlerinin alındığı bu dönemde boşlukları kapatmak için devreye girmektedir. Bugün ekonomik anlamda dijital araçlar, çalışmanın, alışveriş yapmanın hatta okula gitmenin anlamını değiştirmiştir. Salgın ile birlikte uzaktan çalışma modellerine geçilmesi geleneksel çalışma süreçlerini etkilemiştir. Birçok işyeri salgın nedeniyle kapandığından dolayı dijital ticaret yaygınlaşmıştır. Daha önceleri dijital olarak alışveriş yapmayanlar bile ihtiyaçlarını karşılamak adına çevrim içi alışverişe yönelmektedir. Salgın döneminde ülkemizde yaygınlaşan sanal marketler bunun en bilinen örneklerindendir. Ayrıca bu dönemde teknolojiler gelişmeler dağıtım ve hizmet sunumunda değişiklikleri de tetiklemiştir. Örneğin, temassız teslimat, dronların kullanıldığı 
otonom teslimat gibi farklı dağıtım hizmetleri devreye girmiştir. Yeni süreç ayrıca dijital içerik tüketimini de etkilemektedir. Evlere kapanan insanlar ekonomik ihtiyaçlarının dışında eğlence ihtiyaçlarını karşılamak için dijital içerik sağlayııılara yönelmektedir. Dijital içerik üreticisi Netflix dünya çapındaki salgın önlemleri sonrası abone sayısını artırmıştır. Firma sadece, yılın ilk üç ayında yaklaşık 16 milyon kişinin hesap oluşturduğunu ifade etmiştir. Bu, 2019 yılında oluşturulan yeni kayıtların neredeyse iki katıdır (BBC News, 2020).

Dijitalleşme sanal paraların ortaya çıkışına da zemin hazırlamıştır. Bitcoin gibi anonim kripto para birimlerinin yaygınlaşması, kara para aklama ve diğer yasadışı faaliyetleri tetiklemiştir. Blok zinciri para birimlerinin altındaki temel teknoloji kullanıcıların ilgisini çekmektedir. Sanal para kullanımı daha hızlı ve daha güvenli aktarılmasına karşın ateşli silahlar, bilgisayar korsanlığı ya da sanal uyuşturucu ticareti gibi alanlarda kullanıldığından dolayı tartışma konusudur (Mühleisen, 2018, s. 6).

\subsection{Dijital Hayat ve Teknolojik Sorunlar}

Dijitalleşmenin ortaya çıkardığı teknolojik ürün yelpazesi hem çevrim içi hem de çevrim dışı ilişkileri karmaşık hale getirmiştir. Bugün özellikle Kovid-19'unda etkisiyle evlerine kapanan insanlar dijital araç ve ortamlara yönelmiştir. Dijital içerikler sahip oldukları büyük verilerle birlikte sınırları aşmaktadır. Dijital teknolojilerin sağladığı imkânlarla hangi içeriğin üretildiği, nasıı veya nerede kullanıldığı sürekli değişim göstermektedir. Ancak dijital teknolojilerin yayılması genele bakıldığında dünyayı sayısız alanda olumlu etkilemiştir. Örneğin, diğer insanlarla iletişim kurma ve bilgiyi paylaşma süreci en nihayetinde bilgiye erişme becerisi konusunda bir devrim yaratmıştır (United Nations, 2019, s. 6).

Dijitalleşme $A B$ tarafından dikkatle takip edilen konulardan birini oluşturmaktadır. $A B^{\prime} y e$ göre dijitalleşme Avrupa'nın karşılaştığı birçok zorluğa çözüm sağlama potansiyeline sahip bir olguyu temsil etmektedir. AB dijital teknolojileri yalnızca insanların iletişim şeklini değil bundan çok daha kapsamlı bir şekilde insanların yaşama ve çalışma şeklini değiştiren bir süreç olarak kabul etmektedir. Kovid-19 salgınıyla birlikte dijitalleşmeye daha fazla önem verilmesi AB'nin de ilgisini çekmektedir. Bu nedenle teknolojik geçişi hızlandırmak için çalışmalar yapılmaktadır. Avrupa Birliği Liderler Zirvesinde bu konu detaylıca ele alınmıştır. AB ülkeleri Mart 2021 tarihine kadar AB'nin 2030 yılına yönelik olan dijital hedeflerinin belirleneceği kapsamlı bir dijital pusulanın hazırlanması hususunda teşvik edilmektedir. $A B^{\prime}$ nin önem verdiği teknoloji tabanlı alanlar oldukça çeşitlidir. Süper bilgisayarlar, kuantum hesaplama süreçleri, blok zinciri teknolojileri, insan merkezli yapay zekâ gelişmeleri de dâhil olmak üzere yeni nesil dijital teknolojilerin Avrupa'daki gelişiminin teşvik edilmesi amaçlanmaktadır. Aynı zamanda özellikle salgın sürecinde insanların sanal ortama yönelmesiyle birlikte internet ağlarının gelişimi güvenli ağ altyapılarının dağııımının hızlandırııması amaçlanmaktadır (European Council, 2020, s. 2-11).

Teknolojilerin geniş kapsamlı olarak etkileme gücü birçok uluslararası raporda dile getirilmektedir. Son dönemde raporlarda üstünde durulan teknolojiler temel olarak 5 farklı biçimdedir. Bunlardan ilki süper bilgisayar (ubiquitouscomputing) olarak adlandırılan çok farkı işlemi saniyeler içerisinde yerine getiren sistemlerdir. ikincisi her yerde bilgi işlem gücüne erişimi sağlayan işbirliği teknolojileri (collaborationtechnologies)'dir. Üçüncüsü, gerçekliğin birebir kopyalandığı, fiziksel dünyayı dijitale entegre etme yeteneği olan alternatif gerçeklik (extendedreality) teknolojisidir. Dördüncüsü makinelere insan yeteneği kazandırma girişimi olan YZ çalışmalarıdır. Son olarak üzerinde durulan teknolojilerden biri de bilgisayarlar üzerinden gizlilik, güvenlik ve alışveriş yeteneklerini değiştiren blok zinciri (blockchain) teknolojileridir. Tüm bunlar dijital dünyanın dönüşümüne katkı sağlayan ve uluslararası raporlarda teknoloji başlıklı konularda ele alınan konuları oluşturmaktadır.

Raporlarda ele alınan bir başka konu teknolojinin sorumluluğu ve hesap verebilirliği üzerinedir. Otonom sistemler karar alırken birçok değişkeni içerisinde barındırmaktadır. Ancak örneğin, tıbbi yazılım bir hastalığı yanlış teşhis ettiği durumdaki sorumluluğun kime ait olacağı halen tartışma konusudur. YZ aktörleri, hukukun 
üstünlüğüne, insan haklarına ve demokratik değerlere saygı göstermelidir. Bunlar arasında özgürlük, mahremiyet, veri koruma, eşitlik, çeşitlilik, adalet bulunmaktadır. YZ aktörleri, YZ sistemlerine ilişkin şeffaflığı ve sorumlu açıklamayı taahhüt etmelidir. Bu amaçla, bağlama uygun ve son teknoloji ile tutarlı anlamlı bilgiler sağlamalıdırlar. YZ sistemlerine ilişkin genel bir anlayış geliştirmek, insanların YZ sistemleriyle etkileşimlerini farkında kıımak, mantığa dayalı sonuçlar alınmasını sağlamak temel amaç olmalıdır (OECD, 2019). Bugün pandemi ile birlikte dijital süreçler değişmektedir. Örneğin, sağlık alanında kullanılan YZ ve veri analitiği, Tayvan'ın enfeksiyon riskini tahmin etmesine yardımcı olmuştur. Çin ise insan temasını en aza indirmek için dronlar ve robotlar kullanmaktadır (Walcott, 2020).

Uluslararası raporlarda üzerinde durulan ortak konulardan biri insanlar için çalışan teknolojilerin oluşturulmasıdır. İnsanlar için çalışan teknoloji olgusu birçok ülkenin dijital stratejisini temsil etmektedir. Tüm Avrupalılar için dijital becerilere yatııı yapılması, insanların siber tehditlerden (bilgisayar korsanlığı, kimlik hırsızığı) korunması, YZ'nin insanların haklarına saygı duyan ve güvenlerini kazanan şekillerde geliştirilmesini sağlamak önemli stratejilerdir (European Commission, 2019). Her geçen gün siber güvenlik tehditleri ve siber suçların sayısı artmaktadır. Dijitalleşme ile birlikte süreçler karmaşıklaştıkça uluslararası kuruluşlar bunların önüne geçilmesi için tavsiye raporları ortaya koymaktadır. Raporlarda, dijital altyapının, iletişim ağlarının bütünlüğü, güvenliğinin korunması gerektiğinin üzerinde durulmaktadır. Ekim 2020'deki AB Bakanlar Konseyi toplantısında $A B^{\prime}$ nin kendisini siber tehditlere karşı koruma, özellikle kuantum şifreleme yoluyla güvenli bir iletişim ortamı sağlama, yargı ve kanun yaptırımı amacıyla verilere erişim sağlama becerisinin artırııması çağrısında bulunulmuştur (Council of the European Union, 2020). Ayrıca Kovid-19'un dünya çapındaki siber saldııılar ile bağlantıı olduğu tespit edilmiştir. Sadece ABD'de, 2020 Şubat-Mayıs ayları arasında hastaneler ve sağlık hizmeti sağlayıcılarına yönelik siber ihlaller \%50 oranında artış göstermiştir. DSÖ'da Kovid-19 döneminde siber saldıılar konusunda beş kat artışa tanık olduklarını ifade etmiştir (WHO, 2020).

Dijital süreçlerin yükselişte olduğu bir dönemde, ortaya çıkan gelişmelerin nasıl yönetileceği, ulusal ve uluslararası düzeyde çok tartışılan bir konudur. BM Genel Sekreteri, her bir ülkenin benimsediği internet ve YZ stratejisinin yanı sıra baskın para birimi, ticaret, finans kuralları ve çelişkili askeri görüşlere sahip dünya güçleri arasında 'büyük bir kırılma' olduğu konusunda uyarıda bulunmaktadır. Böyle bir bölünme, dijital bir Berlin Duvarı oluşturabilir. Devletlerarasındaki dijital işbirliği, güvenlik, insan hakları ve sürdürülebilir kalkınma amacıyla küresel standartları yansıtan evrensel bir siber uzay politikalarının oluşturulması giderek daha önemli görülmektedir (United Nations, 2019).

\subsection{Dijital Hayat ve Sosyo-kültürel Etki}

Son 10 yıl içerisinde dijitalleşme sosyal ve kültürel yaşamı önemli ölçüde değiştirmiştir. Gündelik yaşam açısından bakıldı̆̆ında insanların büyük bir kısmı iletişimlerini, işlerini dijital ortam üzerinden yürütmektedir. Bu nedenle günlük yaşam pratiği içinde dijital araçların olmadığı bir dünyayı hayal etmek oldukça güçtür. Dijital dönüşüm toplum üzerindeki birçok farklı alana yayılmışır. Sosyo-kültürel etki bakımından bakıldığında özellikle Kovid-19 salgınıyla birlikte dijital süreçlerin eğitimi dönüştürdüğü görülmektedir. Eğitimde dijitalleşme, dijitalleşmenin en önemli alanlarından biri olarak kabul edilmektedir. Uzmanlar, eğitimin dijitalleşmesinin, eğitim kurumlarında yeterli sayıda bilgisayarın, laboratuarların bulunması ve eğitim sürecinin çeşitli eğitim kaynaklarına erişim sağlayan programları ile donatılması olarak tanımlamaktadır. Ayrıca uzmanlar, birçok eğitim kurumunun modern bilimsel araştırmaların yer aldığı elektronik kütüphanelerle donatılması gerektiğini ifade etmektedir (Klyushina, Shalifova, \&Stoykovich, 2021). Öğrencilerin giderek değişken, belirsiz, karmaşık bir dünya karşııında eğitiminin sağlanması oldukça önemli bir konudur. Bilimsel bilgi patlaması ve giderek artan bir dizi karmaşık toplumsal sorunla karakterize edilen bir çağda, müfredatın dijital süreçleri kapsayacak şekilde ele alınması gerekmektedir. OECD belirlediği “Education 2030" stratejisiyle BM'nin 2030 yılına kadar olan sürdürülebilir kalkınma hedeflerine katkıda bulunmaktadır. Bu bağlamda okuryazarlık ve aritmetik süreçlerin dijital süreçlerle birleştirilmesi oldukça 
önemlidir. Dijital dönüşüm çağında büyük verilerin ortaya çıkmasıyla birlikte, dijital okuryazarlık, veri okuryazarlığı, fiziksel sağlık ve zihinsel esenlik konuları giderek daha önemli hale gelmektedir (OECD, 2018, s. 34).

Kovid-19 salgını bir kriz ortamı ortaya çıkarmıştır. Dijital uçurumun daha da fazla görüldüğü salgın döneminde dijital araçlara erişimdeki eşitsizlik gibi birçok sorun daha çarpıcı bir biçimde ön plana çıkmaktadır. UNESCO'ya göre bu durum hükümetlere, teknolojik engelleri kaldırmak, bağlantı maliyetlerini düşürmek, dijital altyapıya ve dijital okuryazarlığa daha fazla yatırım yapılması gerektiğini göstermiştir. Ancak internete erişebilecek kadar şanslı olan çocuklar için pandemi, eğlence veya öğrenme gibi amaçlarla değerlendirilse bile bağlantı sürelerinin artması, çevrim içi platformlara bağımlılıkları arttırması, siber zorbalık gibi riskleri de beraberinde getirmesi bakımından oldukça sıkıntılıdır (UNESCO, 2020, s. 4).

Dijital uçurum genel olarak toplumların daha az gelişmesiyle ilişkilendirilmektedir. Ancak teknolojinin popülerleşmesiyle birlikte ortadan kalkacak geçici bir durum olarak da değerlendirilmektedir. Dünya genelinde internet erişimi olan elektronik cihazlar fazlalaşmasına karşın dijital bölünme bugün de devam etmektedir. Pandemi krizi, eğitimdeki dijital uçurumun etkilerini göstermiştir. Dijital uçurumun yaşandığı bölgelerdeki durum ise değişiklik göstermektedir (Şekil1):

Şekil 1: Dünyadaki internet kullanım durumları

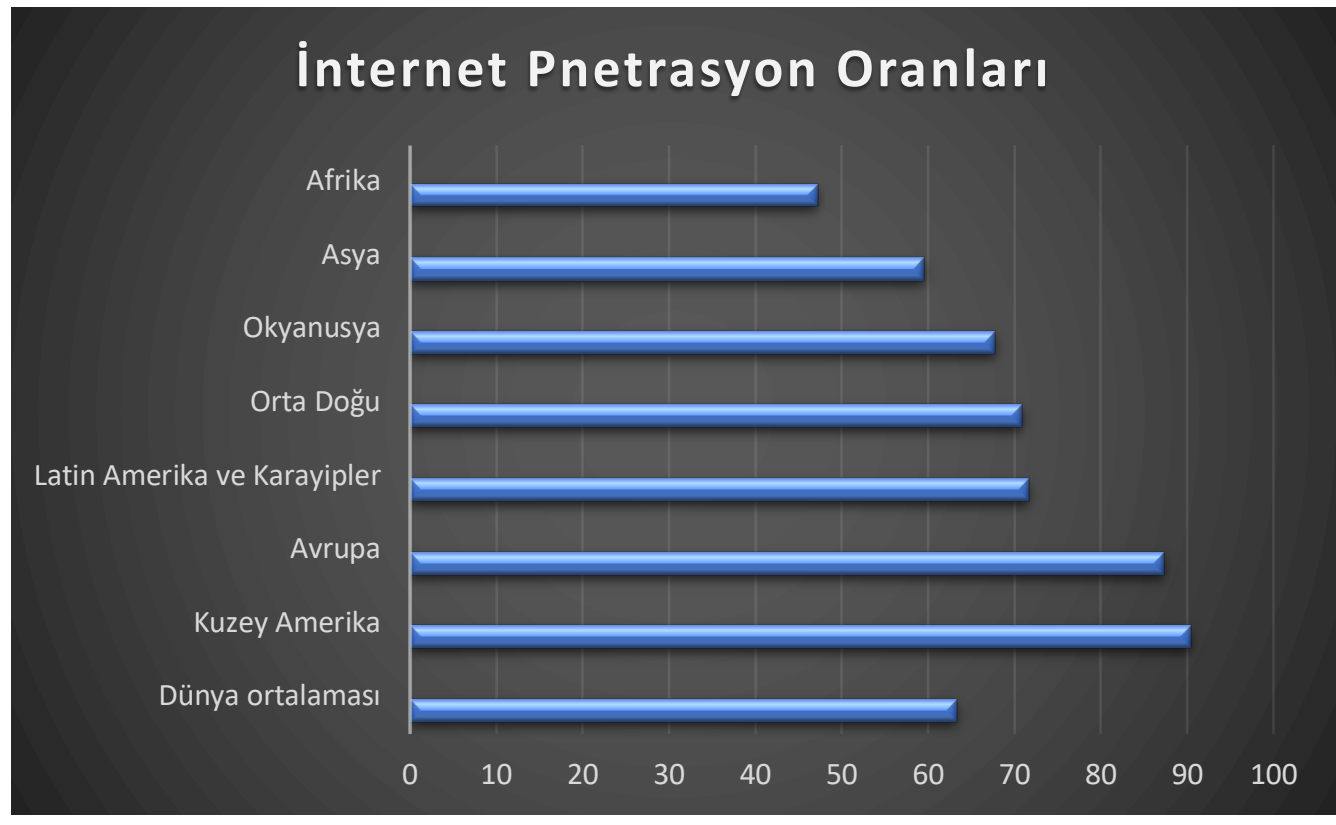

Kaynak: (Internet World Stats 2020)

Bilişim teknolojilerindeki eşitsizlik anlamına gelen dijital uçurum her geçen gün artmaktadır. Bölgeler açısından bakıldığında fark oldukça değişkendir. İnternet kullanım verilerini toplayan İnternet World Stats portalından Ekim 2020 itibarıyla elde edilen verilere göre, Afrika'da yaşayanların sadece \%47,1'i internet erişimine sahipken, Avrupalıların \%87,2'si ve Amerikalıların ise \%90,3'ü internet erişimine sahiptir. Küresel nüfus büyümeye etmektedir. Göç, kentleşme ve artan sosyo-kültürel çeşitlilik ülkeleri ve toplulukları yeniden şekillendirmektedir. Dünyanın büyük bir bölümünde, yaşam standartları ve yaşam şanslarındaki eşitsizlikler büyümektedir. Dijital değişim süreci yeni iş alanları ve farklı yeteneklere yönelik ilgiyi artırmaktadır. Bu durum sosyo-ekonomik anlamda bölünen bir toplumu ortaya çıkartmaktadır. İş yaşamındaki çarpıcı ve hızlı dönüşüm, 
eğitim, bilgi, yetenek gibi kriterleri sağlayamayanlar bireyler için bir uçurum oluşturmaktadır. Sonuç olarak ekonomik alanda işsizlik artışı gibi durumlar kaçınıImazdır (Orhan \& Genç, 2018, s. 264-275). Dijital teknolojilerin hızlı gelişimine rağmen, bölünmeler devam etmektedir ve dijital teknolojilerin etkileri yaşa, coğrafyaya, eğitim ve gelir düzeylerine göre farklılık göstermektedir (OECD, 2018, s. 6).

Dijitalleşmenin sosyo-kültürel etkilerinden biri de demokratik ve sürdürülebilir açık bir toplumun desteklenmesi üzerinedir. Bu bağlamda AB'nin dijital stratejisini, 2050 yılına kadar Avrupa'nın iklim açısından desteklenmesi, dijital sektörün karbon emisyonlarını azaltmak için kullanılması, vatandaşlara dijital veriler üzerinde daha fazla kontrol ve koruma sağlayan mekanizmaların işletilmesi gibi hedefler oluşturmaktadır. Tüm bu hedeflenen mekanizmaların işletilmesi ise güvenilir medya içeriklerinin teşviki ve çevrim içi dezenformasyonla mücadeleden geçmektedir (European Commission, 2019). Bu konu etik başlı̆ında değerlendirilmiştir.

Dönüşüm geçiren alanlardan biri de hukuktur. Adaletin dijitalleşmesi Avrupa ülkelerinin en çok üzerinde durduğu konulardan biridir. Üye devletlerin yargı sistemlerinin daha fazla dijitalleşmesi, vatandaşlar ve hukuk kurumları için erişimi iyileştirebilir, mahkeme işlemlerinin etkinliğini ve verimliliğini artırabilir. Bazı AB ülkeleri, adalet alanında dijital araçları çoktan kullanmaya başlamıştır. Örneğin, dijital mahkeme işlemlerinin yürütülmesi, taraflar arasında elektronik iletişim belgelerin sağlanması gibi işlemler çeşitli sistemler üzerinden yürütülmektedir (Council of the European Union, 2020). Nitekim ülkemizde de bu konuda bilişim araçları sistemleri (SEGBiS) üzerinden ifade alınması gibi süreçler yürütülmektedir.

\subsection{Etik Yaklaşım}

Raporlarda etik yaklaşım genel olarak ortaya çıkan yeni teknolojilerinin sınırlılıları üzerine odaklanan değerlendirmeleri içermektedir. Bu anlamda dijitalleşmeye etki etmesi gereken ortak kabullerin bütününe dijital etik genel başığını kullanmak mümkün görünmektedir. Dijital etik sadece veri koruma ve veri gizliliği sınırlarını belirlemek veya insancıl bilgi teknolojileri sistemi tasarımı için neyin gerekli olduğunu araştırmak ile ilintili çalışmaların sınırlarına hapsedilemeyecek kadar geniş bir açıdan değerlendirilmesi gereken bir konudur. Dijital etik kavramı, YZ, makine öğrenimi, nesnelerin interneti, biyoteknolojinin insan hayatına etkileri, doğanın nasıl etkileneceğini gibi ayrı ayrı ahlaki olarak her bir yeni teknoloji ve durum için doğru eylem standartlarının sorgulanması olarak tanımlanabilir. Karmaşık tedarik zincirlerinde üretim koşullarındaki değişiklikler, teknolojinin kullanıııların günlük yaşamları üzerindeki etkileri ve iş̧̧ilerin çalışma koşulları üzerindeki etkileri de dijital etik şemsiyesi altında yer almaktadır. Dijital etik ilkeleri, bir dizi değer ve standart aracılı̆ııla, dijital dönüşüm sürecine rehberlik edebilir. Bu yönergeler bağlama özeldir ve her yeni teknoloji toplum için uyarlanmayı gerekmektedir (Pwc, 2020, s. 6).

21. yüzyılda, daha önce benzeri görülmemiş bir ölçekte bilginin silahlandırılmasına tanık olunmuştur. Güçlü yeni teknoloji, içeriğin manipülasyonunu ve üretimini basitleştirmektedir. Sosyal ağlar, oto kontrol sağlamadığından dolayı pazarlanan yalanlar çarpıcı bir şekilde artmaktadır. Platformlar, dijital propaganda ve trol orduları için verimli bir zemin haline gelmiştir (UNESCO, 2018, s. 15). Teknolojinin yanlış kullanımı veya kötüye kullanılması, sistemik ırkçılı̆̆ı artırabilir ve marjinalleştirilmiş grupların insan haklarına etkisini ortaya çıkarabilir. Örneğin bir çalışma, yüz tanıma algoritmalarının siyahi kadınları \%35'e kadar yanlış sınıflandırdığı sonucuna varmıştır (Buolamwini \& Gebru, 2018). Dijital süreçlerle birlikte iletişim açısından görülen olumsuz durumlarda bulunmaktadır. 3 farklı enformasyon paylaşım türü üzerinden görülen bir iletişim kullanımı söz konusudur (Şekil2): 


\section{Şekil 2: Enformasyon arasındaki farklılıklar}

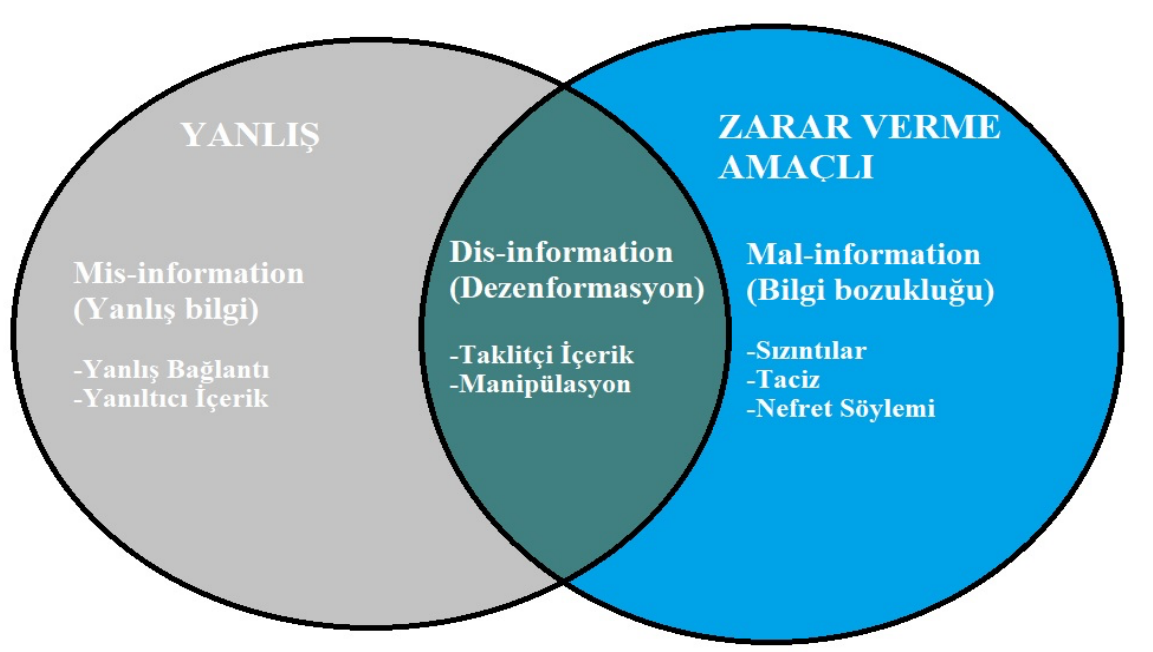

Kaynak: (Karlova \& Fisher, 2013)

Sosyal medya platformları dezenformasyon ve yanlı̧ bilgi oluşturma süreçlerine katkı sağlamaktadır. Herkesin haber sürecinin bir parçası olması nedeniyle, sosyal ağlar merkezi eşik bekçilerinin kaybolmasına neden olmuştur (Colón, 2017). Dijital platformlarda etkisini gösteren bu üç tür birbirinden ayrılmaktadır. Yanıltıcı bilgi (misinformation): Dezenformasyonun paylaşıldığında genellikle yanlış bilgiye dönüşmesi anlamına gelmektedir. Yanlış bilgi aynı zamanda yanlış içeriği de tanımlar ancak paylaşan kişi bunun yanlış veya yanılıcı olduğunun farkına varmaz (Wardle, 2019, s. 8-9). Dezenformasyon (disinformation): Kasıtlı olarak yanlış oluşturulan ve zarar vermek üzere tasarlanmış içeriktir. Bilgi bozukluğu (mal-information) ise gerçekliğe dayanan, bir kişiye, sosyal gruba, kuruluşa veya ülkeye zarar vermek için kullanılan bilgileri ifade etmektedir (UNESCO, 2018).

Sosyal medya tüm küresel nüfusun neredeyse yarısını birbirine bağlamaktadır (Kemp, 2019). Insanların seslerini duyurmalarını ve gerçek zamanlı olarak dünyanın her yerinden insanlarla konuşmalarını sağlamaktadır. Bununla birlikte, dijital ortamda bilginin gerçek olup olmadığı süreci karmaşıktır. Haber açısından bakıldığında tıklanma amaçı atılan başııklar, baştan savma içeriklerle son derece aldatıcı olabilmektedir. Ayrıca sosyal medya nefret söylemine ve yanlış bilgilendirmeye yol açarak önyargıları güçlendirebilmektedir (Amazeen, 2015). Bu şekliyle sosyal medya algoritmaları dünyadaki toplumların parçalanmasını tetikleyebilir. Son yıllarda dijital araçlar toplumsal anlamda ortaya çıkardıkları gizlilik konularıyla ilgili çeşitli problemlerle anılmaktadır. Kovid-19 sonrası bir dünyada temassız işlemlerin avantajlarıyla donatılan toplumun gizlilik yönünden endişeleri bulunmaktadır. Nitekim Vatikan'ın "Roma, Yapay Zekâ Etiği Çağrısı", "teknolojik ilerlemenin insan ırkının gelecekteki gelişimine vurgu yapan ve ahlaki bütünlüğüne bağlı kalınan net bir geleceği" öngörmektedir (Copestake, 2020). Özellikle Ocak 2021'de Whatsapp uygulamasını elinde bulunduran şirketin verilerin paylaşılması noktasındaki politikalarını değiştireceğini açıklaması ülkemizde iletişim uygulamalarına karşı olan bakışa olumsuz etki etmiştir nitekim birçok Whatsapp kullanııısı başka platformlara yönelmiştir. Bugün aynı zamanda birçok kamu hizmet varlı̆ı̆na veya mobil uygulamaya gömülü olan teknolojiler, kişisel bir bilgi hazinesi görevi üstlenmektedir. Çoğu zaman bu cihazlar kimi zaman casusluk yapılması amacıyla kullanılmıştır (Telegraph, 2018). Bu nedenle bilgi aktarımı noktasındaki etik durumlarda dikkatle incelenmesi gereken konu başlıklarından birini oluşturmaktadır. 


\section{SONUÇ}

Günümüzde dijital teknolojiler toplumumuzda giderek daha önemli bir rol oynamaktadır. Gelişen teknolojilere ayak uydurma girişimleri, dijital becerileri gerekli kılmaktadır. Bu da dijitalleşmenin hem şirketler hem de vatandaşlar için her zamankinden daha önemli hale gelmesini sağlamıştır. Dijitalleşme süreçleri ve dijital hayat olgusu uluslararası raporlarda geniş bir biçimde ele alınmaktadır. Etkileri bakımından oldukça farklı alanlara uzanan dijitalleşmenin WEF, OECD, UNESCO, AB, AK raporlarında temel olarak ekonomik, teknolojik, toplumsal ve etik yaklaşım açısından ele alındığı gözlemlenmiştir. Raporlarda ekonomik etkiler genel çerçevede iş gücü piyasasının dönüşümü ve ortak bir ekosisteme odaklanırken teknolojik etkiler güvenlik, şeffaflık, sorumluluk, insani denetim gibi mekanizmalar üzerinden değerlendirilmiştir. Sosyo-kültürel etki bakımından ise dijital hayat için etkin politikalar belirlenmesi, kolluk kuvvetlerinin dijital veri kullanımı, sınırlama ve düzenleme eksikliği, dijital eğitim ve e-bilgi konuları üzerinde durulmuştur. Etik yaklaşım açısından ise gizlilik, veri paylaşımı, enformasyon ve iletişim etiği, adalet, insan merkezli değerler gibi olgular raporlarda üzerinde durulan konuları oluşturmaktadır. Yeni teknolojilerin insanların ortak yaşam düşüncesi etrafında oluşturulan normlara, fayda sağlayacak şekilde tasarlanması ve kullanılması etik yaklaşımın en temel dayanağı olarak görülmektedir. Toplumsal değerlerin ve normların yeniden belirlenmesi ve aslında daha ortaya çıkmadan toplumsal sorunların neler olabileceği raporların içeriğinde kestirilmeye çalışılmıştır. Bu açıdan raporların en önemli faydalarından biri sorunlara karşı proaktif bir tavrın geliştirilmesini sağlamasıdır.

Teknolojik değişimlerin ortaya çıkardıkları yeniliklere bakılırsa mevcut düzenin henüz dijital dönüşüme tam olarak ayak uyduramadığı görülmektedir. Dijital teknolojilerin ürettikleri bilgi akışı, çok sayıda çevrim içi eylem birçok dijital "ayak izini” ortaya çıkarmaktadır. Dijital teknolojilerin ve verilerin kullanımı, ekonomilerin ve toplumların tüm sektörlerinde dijital dönüşümün temelini oluşturmaktadır. Büyük veri yığınları bunları kullanan, pazarlayanlar için büyük fırsatlar sunarken, güvenlik ve gizlilikle ilgili ele alınması gereken belirli sorunları ortaya çıkarmaktadır. Özellikle Dünya, salgın ve daha da etkisini artıran dijital teknolojik değişim nedeniyle farklı bir yer olacaktır. Teknolojiler geniş sosyal atılımların ve ekonomik değerlerin yeniden yaratılması noktasında kilit bir rol üstlenmektedir.

Dijitalleşmenin etkileri hakkında sorulabilecek sorular ise oldukça çeşitlidir. Özellikle OECD raporlarında bu konu geniş bir biçimiyle ele alınmaktadır (OECD, 2019). Birçok sorunun çözümünde anahtar rolü üstlenen dijital teknolojiler pandemi dönemiyle birlikte belirli soruları ortaya çıkarmıştır: Dijital dönüşümler başta ekonomi de dâhil olmak üzere tüm sektörlerde nasıl ölçülebilir? Kovid-19 salgınıyla birlikte mevcut iş modellerinin değişmesi ve yenilerinin ortaya çıkışı ekonomiyi nasıl değiştirecek? Pandemi sonrası dijitalleşmenin etkisi nasıl değerlendirilmelidir? Pandemi sonrası dijitalleşmenin ışığında geleceğin ekonomik ve sosyo-kültürel faaliyetleri ne olacak? Dijital dönüşümlerin toplum üzerindeki refaha etkisi farklılaşacak mı? Evde kalması gereken birçok insana eğitim nasıl verilmeye devam edecek? Dijitalleşme süreçleriyle birlikte dijital haklar gerçek anlamda korunacak mı? gibi birçok soru çözümlenmeyi beklemektedir. Ancak temel olarak dijital teknolojilerin potansiyelinden yararlanılan, vatandaşların korunduğu, temel hizmetlerin dijital ortamdan kolayca verildiği, ekonomik, sosyo-kültürel etkileşimlerin toplum için faydalı bir biçimde desteklendiği, teknoloji kullanımına öncelik verirken insan haklarının korunduğu bir politikanın benimsenmesi sorunların çözümü noktasında önemli bir başlangıç olacaktır. Hükümetlerin güvenilir bir dijital ekosistemin geliştirilmesi yönünde uluslararası raporları dikkatle izlemesi de geçiş sürecinin kolaylaşmasına yardımcı olacaktır. 


\section{KAYNAKÇA}

Önür, N., \& Kalaman, S. (2016). Dijital Gündelik Yaşam: Yeni Toplumsallıklar Ve Dijital Yabancılaşma. Akademik Sosyal Araştırmalar Dergisi, 269-289.

BBC News. (2020, 04 21). Netflix gets 16 million new sign-ups thanks to lockdown. 01 26, 2021 tarihinde https://www.bbc.com/news/business-52376022 adresinden alındı

Bilgin, N. (2006). Sosyal Bilimlerde Iç̧erik Analizi Teknikler ve Örnek Çalışmalar. Ankara: Siyasal kitabevi.

Bleicher, J., \& Stanley, H. (2018). Digitization as a Catalyst for Business Model Innovation a Three-step Approach to Facilitating Economic Success. Journal of Business Management, 4(2), 62-71.

Bukht, R., \& Heeks, R. (2017). Defining, Conceptualising and Measuring the Digital Economy. International Organisations Research Journal, 13(2), 143-172.

Buolamwini, J., \& Gebru, T. (2018). Gender Shades: Intersectional Accuracy Disparities in Commercial Gender Classification. Proceedings of the 1st Conference on Fairness, Accountability and Transparency (s. 7791). New York: Association for Computing Machinery.

Castells, M. (2010). The Rise of the Network Society: Information Age: Economy, Society, and Culture. New Jersey: Wiley-Blackwell.

Colón, A. (2017, 02 07). You are the new gatekeeper of the news. 02 17, 2021 tarihinde The Conversation: https://theconversation.com/you-are-the-new-gatekeeper-of-the-news-71862 adresinden alındı

Copestake, J. (2020, 02 28). Al ethics backed by Pope and tech giants in new plan. 01 17, 2021 tarihinde BBC: https://www.bbc.com/news/technology-51673296 adresinden alındı

Council of the European Union. (2020). Digital Europe: Council adopts new rules to modernise judicial cooperation in taking of evidence and service of documents. Brussel: Council of the EU.

Council of the European Union. (2020). New Cybersecurity Competence Centre and network: informal agreement with the European. Brussel: European Council.

European Commission. (2019). Shaping Europe's digital future. 02 07, 2021 tarihinde https://ec.europa.eu/info/strategy/priorities-2019-2024/europe-fit-digital-age/shaping-europedigital-future_en adresinden alındı

European Commission. (2020). Communication from the Commission to the European Parliament, the Council, the European Economic and Social Committee and the Committee of the Regions. Brussels: European Commission.

European Council. (2020). Special European Council, 1-2 October 2020. Brussel: Council of the European Union.

$\begin{array}{lllllll}\text { European } & \text { Parliament. } & \text { (2016). Industry } & \text { 4.0. } & 01 & 19, & \text { tarihinde }\end{array}$ https://www.europarl.europa.eu/RegData/etudes/STUD/2016/570007/IPOL_STU(2016)570007_EN.p $\mathrm{df}$ adresinden alındı

Gökçe, O. (2006). İçerik Analizi Kuramsal ve Pratik Bilgiler. Ankara: Siyasal kitabevi.

Holsti, O. (1969). Content Analysis for the Social Sciences and Humanities. Boston: Addison-Wesley Publishing Company. 
Küçükvardar, M., Aslan, A., \& Bayrakcı, S. (2020). Yapay Zekâ Ve Etik Üzerine Bir Araştırma. ATLAS Journal International Refereed Journal On Social Sciences, 1065-1077.

Karlova, N., \& Fisher, K. (2013). A social diffusion model of misinformation and disinformation for understanding human information behaviour. Information Research, 18(1).

Kemp, S. (2019, 01 30). Digital 2019: Global Internet Use Accelerates. 02 06, 2021 tarihinde Wearesocial: https://wearesocial.com/blog/2019/01/digital-2019-global-internet-use-accelerates adresinden alındı

Keskin, B. (2020). Endüstri 4.0 ve Büyük Veri. Endüstri 4.0 Paradigması: İ̧sletme Fonksiyonlarının Dijital Dönüşümü. İstanbul: Efe Akademi Yayınevi.

Mühleisen, M. (2018). The Long and Short of The Digital Revolution. Finance and Development, 55(2), 4-8.

McKinsey Global Institute. (2017). Jobs lost, jobs gained: Workforce transitions in a time of automation. Chicago: McKinsey Company.

OECD. (2018). Future of Education and Skills 2030. Paris: Organisation for Economic Co-operation and Development.

OECD. (2018). Transformative technologies and jobs of the future. Paris: Organisation for Economic Co-operation and Development.

OECD. (2019). 02 11, 2021 tarihinde Organisation for Economic Co-operation and Development: https://www.oecd.org/going-digital/ai/principles/ adresinden alındı

OECD. (2019). Measuring the Digital Transformation: A ROADMAP FOR THE FUTURE. OECD Going Digital project.

OECD. (2019). Recommendation of the Council on Artificial Intelligence. Paris: Organisation for Economic Cooperation and Development.

Orhan, A., \& Genç, S. (2018). Bilişim Teknolojisindeki Gelişimin Sosyoekonomik Etkileri. Yönetim ve Ekonomi Araştırmaları Dergisi, 264(1), 64-275.

Pwc. (2020). Digital Ethics Orientation, Values and Attitudes for a Digital World. PWC.

Reinartz, W., Wiegand, N., \& Imschloss, M. (2019). The Impact of Digital Transformation on the Retailing Value Chain. International Journal of Research in Marketing, 36(3), 350-366.

Rosengren, K. (1981). Advances in Content Analysis. California: Sage Publications.

Serrano-Puche, J. (2015). Emotions and Digital Technologies: Mapping the Field of Research in Media Studies. MEDIA@LSEWorking Paper Series. MEDIA@LSE.

Telegraph. (2018, 05 11). Jealous Husband Used Wall-Mounted iPad in his 'Smart Home' to Spy on Estranged Wife. 01 24, 2021 tarihinde Telegraph News: https://www.telegraph.co.uk/news/2018/05/10/smarthome-stalker-jealous-husband-used-wall-mounted-ipad-heating/ adresinden alındı

UNESCO. (2018). Journalism, 'Fake News' and Disinformation: A Handbook for Journalism Education and Training. Paris: UNESCO Series on Journalism Education.

UNESCO. (2020). The Digital Transformation of Education: Connecting Schools, Empowering Learners. Paris: UNESCO Broadband Commission for Sustainable Development.

UNESCO. (2020). The Digitization of TVET and Skills Systems. Geneva: International Labour Organization. 
United Nations. (2019, 04 1). Green economy could create 24 million new jobs. 02 11, 2021 tarihinde https://www.un.org/sustainabledevelopment/blog/2019/04/green-economy-could-create-24-millionnew-jobs/ adresinden alındı

United Nations. (2019). The Age of Digital Interdependence. New York: United Nations Secretary General's High Level Panel on Digital Cooperation.

Walcott, D. (2020, 07 1). How the Fourth Industrial Revolution can help us beat COVID-19. 02 05, 2021 tarihinde WEF: https://www.weforum.org/agenda/2020/05/how-the-fourth-industrial-revolution-can-help-ushandle-the-threat-of-covid-19/ adresinden alındı

Wardle, C. (2019). Understanding Information Disorder. First Draft.

Weber, R. (1990). Content Analysis. New Delhi: Sage Publications.

WEF. (2021). Global Technology Governance Report 2021: Harnessing Fourth Industrial Revolution Technologies in a COVID-19 World. Cologny: WEF.

WEF. (2021). The World Economic Forum. 01 19, 2021 tarihinde WEF: https://www.weforum.org/about/worldeconomic-forum adresinden alındı

WHO. (2020, 04 23). WHO reports fivefold increase in cyber attacks, urges vigilance. 01 26, 2021 tarihinde World Health Organization: , https://www.who.int/news-room/detail/23-04-2020-who-reports-fivefoldincrease-in-cyber-attacks-urges-vigilance adresinden alındı

Wirtz, B. (2019). Digital Business Models: Concepts, Models, and the Alphabet Case Study. Berlin: Springer. 
Etik kurul onayı: Etik kurul onayına ihtiyaç bulunmamaktadır.

Yazar katkı oranları: Yazarların makalenin genel yazımına katkı oranları birinci yazar (Mert Küçükvardar) \%60, ikinci yazar (Alaattin Aslan) \%40 şeklindedir. Literatür taramasında birinci yazar $\% 60$, ikinci yazar \%40 düzeyinde katkı sağlamıştır. İçerik analizi yöntemi ile raporların kategorileştirilmesi birinci yazar tarafından yapılmıştır. Uluslararası raporların belirlenen 4 kategori açısından değerlendirilmesinde birinci yazar \%60, ikinci yazar \%40 oranında katkıda bulunmuştur. Yazarların sonuç ve öneriler bölümünün oluşturulmasındaki katkı oranları birinci yazar \%60, ikinci yazar \%40 şeklinde belirtilmiştir.

Ethics committee approval: There is no need for ethics committee approval.

Author contribution rate: The contribution percentages of the authors to the general writing of the article are $60 \%$ for the first author (Mert Küçükvardar) and $40 \%$ for the second author (Alaattin Aslan). In the literature review, the first author contributed $60 \%$ and the second author contributed $40 \%$. The categorization of the reports by the content analysis method was done by the first author. The first author contributed $60 \%$ and the second author $40 \%$ according to the evaluation of international reports in terms of 4 categories. The contribution rates of the authors in the creation of the conclusion and recommendations section were stated as $60 \%$ for the first author and $40 \%$ for the second author.

Bu çalışma araştırma ve yayın etiğine uygun olarak gerçekleştirilmiştir. 